Agro-Science Journal of Tropical Agriculture, Food, Environment and Extension Volume 19 Number 4 (October 2020) pp. $43-50$

ISSN 1119-7455

\title{
CLASSIFICATION AND SUITABILITY EVALUATION OF SOILS ALONG A TOPOSEQUENCE FOR RICE PRODUCTION IN ALABATA, SOUTHWEST NIGERIA
}

\author{
"Osinuga O.A., Aiboni V.U. and Oyegoke C.O. \\ Department of Soil Science \& Land Management, College of Plant Science \& Crop Production, \\ Federal University of Agriculture, P.M.B. 2240, Abeokuta, Nigeria \\ *Corresponding author's email: olufemi500@yahoo.com; osinugaoa@funaab.edu.ng
}

\begin{abstract}
Soil classification and suitability evaluation are requirements for attaining optimum utilization of the available land resources. Detailed soil survey of a top sequence at Alabata, Southwest Nigeria was carried out using the rigid grid method. The soils were characterized, classified, and evaluated for rain-fed rice production. The results of the study showed that the soils were loamy sand to sandy clay loam texture, fine to coarse sub-angular blocky structure and loose to hard consistency. Soil reaction ranged from strongly acidic to slightly acidic (pH 4.2-6.1) with low organic carbon $(5.6-19.0 \mathrm{~g} / \mathrm{kg})$ and total nitrogen $(0.5-1.7 \mathrm{~g} / \mathrm{kg})$. The potassium contents were moderate while exchangeable cations and available phosphorus were very low. Pedon 1 was classified as KandicPaleustalfs, pedon 2 as TypicHaplustalfs and pedon 3 as Aeric Kandiaqualfs. The index of current productivity (IPc) by linear model ranged between 8.7 and 10.3, while by square root models ranged between 16.2 and 17.5. The values suggested that the soils were not currently suitable (N2 and N1) for rice production. The index of potential productivity (IPp) ranged from 48.5 to57.0 by linear model and from 53.9 and 58.5 for the square root model. Thus, pedons were potentially marginally (S3) and moderately (S2) suitable for the production of rice. The limiting factors were mainly low levels of macro nutrients, organic matter and cation exchange capacity.
\end{abstract}

Key words: Classification, climate, suitability evaluation, toposequence, rice production

\section{INTRODUCTION}

Rice (Oryza sativa L.) is an important cereal in Nigeria and its consumption has increased enormously, at about $10 \%$ per annum due to changing consumer preferences (Akande, 2003; Ajala and Gana, 2015). Rice has become the main staple and major sources of carbohydrates in the Nigerian people's diet across all socio-economic classes. High demand for rice has led to the importation of this commodity. Nigeria is one of the leading rice importers in the world because rice is produced in the country by small-scale farmers (FAO, 2019). Although total rice production has risen over the last two decades, the rises have not been sufficient to meet the increasing demand of the ever-increasing population due to reliance on rainfed agriculture, smallholder land holding, low level of irrigation development, poor planting material, low fertilizer application, inadequate storage facilities, and a weak agricultural extension system (Ana, 2010; FAO, 2019). The trend in rice production in Nigeria (Figure 1) shows a significant increase in the area put to production between 1961 and 2017 (FAOSTAT, 2018).

Classification of soils for different land uses is the first milestone to develop database for formulating land use models (Singh et al., 2013). Soil classification is a way of grouping soil individuals into more or less homogeneous groups, thereby highlighting the essential differences in soil properties and functions between classes necessary for judicious, beneficial and optimal use on a sustainable basis (Jagdish et al., 2009). Studies relating to soil and site characteristics and crop requirements form the basis for soil suitability evaluation (Meena et al., 2009). Land suitability is the ability of a particular land to tolerate and accommodate the production of crops in a sustainable way that can give optimal yield. Its evaluation provides information on the constraints and opportunities for the use of the land and also guides decisions on potential and optimal utilization of resources, whose knowledge is an essential precondition for land use planning and development (AbdelRahman et al., 2016). Moreover, such analysis allows identification of the main limiting factors for the agricultural production.

This enables decision makers such as land users, land use planners, and agricultural support services to develop crop management practices able to overcome such constraints and increase the productivity. Land suitability of a particular land is a function of matching the land characteristics with the crop requirements (Mustafa et al., 2011).

Please cite as: Osinuga O.A., Aiboni V.U. and Oyegoke C.O. (2020). Classification and suitability evaluation of soils along a toposequence for rice production in Alabata, Southwest Nigeria. Agro-Science, 19 (4), 43-50. DOI: https://dx.doi.org/10.4314/as.v19i4.8 


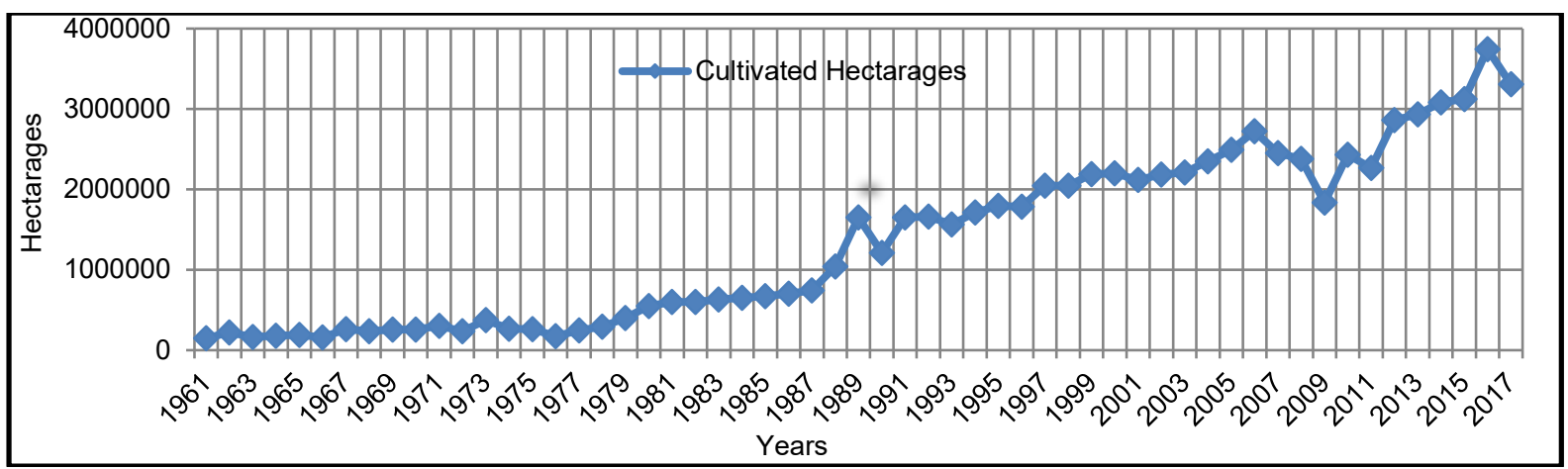

Figure 1: Trend in rice production in Nigeria. Source: FAOSTAT, 2018

Optimizing rice production could be met through a systematic survey of the soils, evaluating their potentials for a wide range of land use options and formulating land use plans which are environmentally benign, socially acceptable and economically viable (Addeo et al., 2001; Sathish and Niranjana, 2010). However, the interest of any farmer lies mainly on how profitable it is to grow a particular crop and what amendments are necessary to optimize the productivity of the soil for the specified crop (Fasina and Adeyanju, 2007). Therefore, the objectives of this study were to characterize, classify, determine the suitability and identify the types of limitations of soils of a toposequence in Alabata, Southwest Nigeria for sustainable and profitable production of rice.

\section{MATERIALS AND METHODS}

\section{Description of the Study Area}

The study was conducted along transect from the crest to the foot slope on the Farm road of Federal University of Agriculture, Abeokuta (Figure 2). The site selection was based on the detailed soil map and land use of the University (Figure 3). The site was located in the northeastern part of Abeokuta within latitude $07^{0} 23^{\prime} \mathrm{N}$ and longitude $03^{0} 26^{\prime} \mathrm{E}$. Geologically, the study area falls within the PreCambrian rocks of southwest, Nigeria basically from Basement Complex rock origin. The major rock types are schist, quartz, granite, gneiss, and migmatite. Most of the upland areas have given way to intensive arable and tree crops farming and the foot slope to nursery of plantation crops and dry season farming (Aiboni, 2001). The climate falls within the sub-humid tropical forest region with two separate seasons; wet season (Apr.-Nov.) and dry season (Dec.-Mar.). The area has a mean annual rainfall of $1000-1500 \mathrm{~mm}$, mean temperature of $27-32^{\circ} \mathrm{C}$, mean relative humidity of $75-95 \%$, and potential evapotranspiration of 218-274 mm (FUNAAB, 2018).

\section{Field Study}

A detailed survey was conducted on a land area of $400 \mathrm{~m} \times 100 \mathrm{~m}\left(40,000 \mathrm{~m}^{2}\right)$ using the rigid grid method of survey with traverses cut at $50 \mathrm{~m} \times 20 \mathrm{~m}$ for the sampling. At each sampling point, samples were collected from the surface to a depth of $60 \mathrm{~cm}$ at $15-\mathrm{cm}$ intervals. The samples collected were described morphologically for colour, texture, consistency, stoniness, root abundance, mottles and others. Similarities in the properties above were used in locating the mapping units. Three mapping units were delineated at the end of the survey, one each at different slope positions. Standard profile pits were dug on each of the units, and coded as Pedon 1 (Upper slope), pedon 2 (middle slope), and pedon 3 (foot slope). In each profile pit, identifiable horizons were sampled for description and labeled accordingly. The different horizons were described following the recommended procedure in the "Guidelines for soil description" (FAO, 2006). Soil samples collected were air-dried for laboratory analyses.

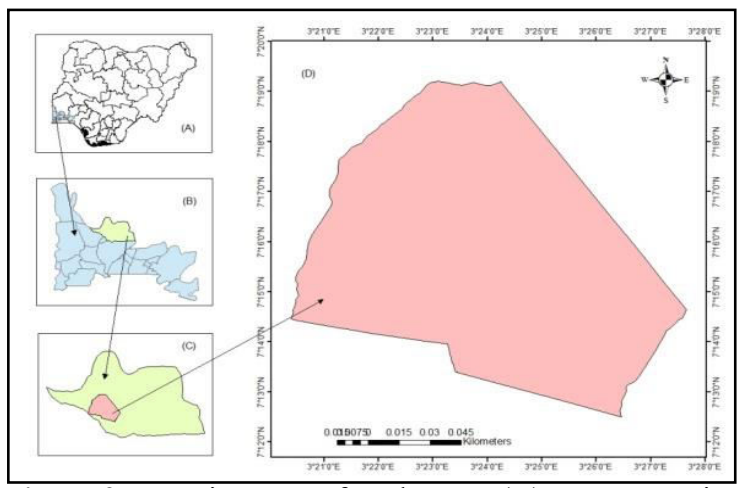

Figure 2: Location map of study area. (A) Ogun State in Nigeria, (B) Odeda Local Government Area in Ogun State, (C) Study Area in Odeda L.G.A., (D) Study Area

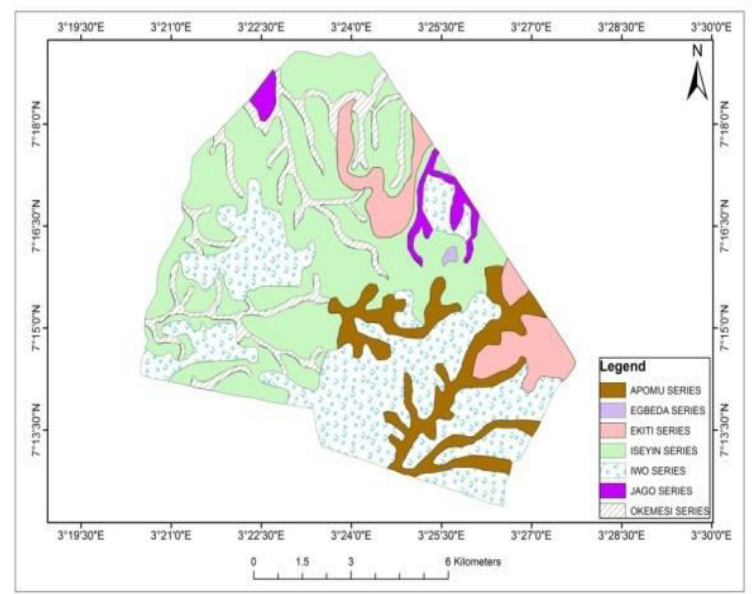

Figure 3: Soil map of the study area (FUNAAB) showing the soil series 


\section{Laboratory Studies}

The air-dried soil samples were ground and sieved by $2 \mathrm{~mm}$ sieve. The gravel contents $>2 \mathrm{~mm}$ were weighed and recorded. Analysis for particle size distribution was carried out using hydrometer method (Gee and Bauder, 1986) using sodium hexameta-phosphate as the dispersing agent. Core samples were oven-dried at $105^{\circ} \mathrm{C}$ to constant weight and the soil bulk density calculated as oven-dried weight divided by cylinder volume (Logan and Harrison, 1995).

The $\mathrm{pH}$ was measured in both soil-water and soil- $\mathrm{KCl}$ suspensions (1:2) electrometrically using the glass electrode $\mathrm{pH}$ meter (IITA, 1982). Soil organic carbon was determined using wet-oxidation method (Walkley and Black, 1934). Total nitrogen was determined by macro-kjeldahl digestion method (Bremmer and Mulvaney, 1982).

Available phosphorus was extracted by Bray-1 extractant (Bray and Kurtz, 1945). The P in the extract was determined by vanado-molybdate blue method (Murphy and Riley, 1962).

Exchangeable acidity $\left(\mathrm{H}^{+}+\mathrm{AI}^{3+}\right)$ was extracted with $1.0 \mathrm{M} \mathrm{KCl}$ and titrated with sodium hydroxide. Exchangeable bases were extracted with $1.0 \mathrm{M}$ ammonium acetate $\left(\mathrm{NH}_{4} \mathrm{OAC}\right)$ at $\mathrm{pH}$ 7. Thereafter, $\mathrm{Ca}^{2+}$ and $\mathrm{Mg}^{2+}$ were determined with atomic absorption spectrophotometer while $\mathrm{K}^{+}$and $\mathrm{Na}^{+}$ were read in a flame photometer (Sparks, 1996). Effective Cation Exchangeable Capacity (ECEC) was obtained by summation of exchangeable bases and total acidity. The base saturation was calculated as the ratio of exchangeable bases to the cation exchange capacity express in percent.
Soil Classification and Land Suitability Evaluation Data obtained from the field and laboratory analyses were used to classify the soil into its appropriate order, suborder, great group, and subgroup following the guideline in the USDA Soil Taxonomy (Soil Survey Staff, 2014) and FAO classification system (FAO-UNESCO, 2015), while local soil classification was carried out using the method of Smyth and Montgomery (1962). Two different methods were used for evaluating soil suitability for rain-fed rice, the non-parametric (Limitation) and Parametric (Index of Productivity) technique. The non-parametric was done through the guidelines provided by Sys et al. (1993) and FAO (2007) for the land suitability evaluation. Each pedon was assigned to a suitability class by matching the land requirements for rice production (Table 1) characteristics with the characteristics of the pedon (Tables 2, 3 and 4).

The most limiting characteristic in a group determines its performance according to Liebig's Law of minimum and this was applied to the performance or suitability of a soil type. The group of land qualities considered for evaluation includes climate (c), topography $(\mathrm{t})$, drainage characteristics (w), soil physical characteristics (s) and soil chemical fertility (f). In computing the potential suitability for rice production, the fertility factors that are affected by fertilizer additions and management practices were excluded. The parametric land evaluation consists of numerical rating of different land characteristics according to numerical scale between the maximum and the minimum value. The climatic indexes and the land index were calculated from these individual ratings. The current suitability was computed linearly using an index of current (actual) productivity (IPc) of Storie (1933):

Table 1: Land/soil requirements for suitability evaluation of rice

\begin{tabular}{|c|c|c|c|c|c|c|c|}
\hline Land Qualities & & $\begin{array}{c}\text { S11 } \\
96-100\end{array}$ & $\begin{array}{c}\text { S12 } \\
86-95\end{array}$ & $\begin{array}{c}\text { S2 } \\
61-85\end{array}$ & $\begin{array}{c}\mathrm{S} 3 \\
41-60\end{array}$ & $\begin{array}{c}\mathrm{N} 1 \\
21-40\end{array}$ & $\begin{array}{c}\mathrm{N} 2 \\
0-20\end{array}$ \\
\hline \multirow[t]{4}{*}{ Climate (C) } & Annual rainfall $(\mathrm{mm})$ & $1200-1500$ & $1000-1200$ & $800-1000$ & 800 & $<800$ & $<800$ \\
\hline & No. of dry months & $0-2$ & $2-3$ & $4-5$ & 6-7 & $>7$ & $>7$ \\
\hline & Mean annual temp. $\left({ }^{\circ} \mathrm{C}\right)$ & $>25$ & $22-25$ & $20-22$ & $18-20$ & $<18$ & $<18$ \\
\hline & Relative humidity (\%) & $>75$ & $70-75$ & $65-70$ & $60-65$ & $<60$ & $<60$ \\
\hline Topography (T) & Slope gradient (\%) & $0-2$ & $3-6$ & $7-15$ & $16-25$ & $>25$ & $>25$ \\
\hline \multirow[t]{2}{*}{ Wetness (W) } & Drainage & Wd & Id & $\mathrm{Md}$ & $\mathrm{Pd}$ & vpd & Vpd \\
\hline & Flooding & F0 & F0 & F1 & $\mathrm{F} 1$ & $\mathrm{~F} 2$ & $\mathrm{~F} 2$ \\
\hline \multirow[t]{3}{*}{ Soil physical properties (S) } & Soil depth (cm) & $>100$ & $75-100$ & $60-75$ & $50-60$ & $<50$ & $<50$ \\
\hline & Surface texture & $\mathrm{C}, \mathrm{SCL}$ & $\mathrm{CL}$ & $\mathrm{SC}, \mathrm{CL}$ & SL, L & LS & $\mathrm{S}$ \\
\hline & Gravel at $0-20 \mathrm{~cm}(\%)$ & $<2$ & $2-4$ & $5-15$ & $16-30$ & $30-35$ & $>35$ \\
\hline \multirow{7}{*}{ Chemical fertility (F) } & $\mathrm{pH}$ in distilled water & $7.5-8.0$ & $7.0-7.5$ & $5.5-7.0$ & $5.0-5.5$ & $4.0-5.0$ & $<4.0$ \\
\hline & Organic matter (\%) & $>5$ & $3-5$ & $2-3$ & $1-2$ & $<1$ & - \\
\hline & Total Nitrogen (\%) & $>0.5$ & $0.4-0.5$ & $0.2-0.4$ & $0.1-0.2$ & $<0.1$ & $<0.1$ \\
\hline & Available P (mg/kg) & $>10$ & $7-10$ & $4-6$ & $2-4$ & $<2$ & $<2$ \\
\hline & Exchange $\mathrm{K}(\mathrm{cmol} / \mathrm{kg})$ & $>0.6$ & $0.4-0.6$ & $0.2-0.4$ & $0.1-0.2$ & $0.05-0.1$ & $<0.05$ \\
\hline & $\mathrm{CEC}(\mathrm{cmol} / \mathrm{kg})$ & $>16$ & $12-16$ & $8-12$ & $5-8$ & $<5$ & - \\
\hline & Base Saturation (\%) & $>75$ & 75 & $50-75$ & $35-50$ & $<35$ & $<35$ \\
\hline
\end{tabular}

S11 (96-100) - No limitation; S12 (86-95) - Slight limitation; S2 (61-85) - Moderate limitation; S3 (41-60) - Severe limitation;

N1 (20-40) - Very severe limitation that can be corrected; N2 (0-19) - Very severe limitation that cannot be corrected.

Source: Modified from Sys et al., 1993; FAO, 2007; Ajiboye et al., 2011 


$$
\mathrm{IPc}=A \times \frac{B}{100} \times \frac{\mathrm{C}}{100} \times \frac{\mathrm{D}}{100} \times \frac{E}{100} \times \frac{F}{100} \ldots \text { (i) }
$$

(c) $\quad(\mathrm{t}) \quad(\mathrm{w}) \quad(\mathrm{s}) \quad(\mathrm{f})$

where, IPc is index of current (actual) productivity, $\mathrm{A}$ is the overall least rating characteristic and $\mathrm{B}$, C....F are the least rating characteristic for each land quality group. The potential suitability (IPp) was similarly computed using the potential index of productivity. The IPc and IPp were also computed using the square root model as stated below:

$$
\operatorname{IPc}=A \times \sqrt{\frac{B}{100} \times \frac{\mathrm{C}}{100} \times \frac{\mathrm{D}}{100} \times \frac{E}{(\mathrm{c})} \times \frac{F}{100} \times \frac{F}{100}} \ldots
$$

\section{Statistical Analysis}

The soil data were analyzed using descriptive statistics to show the relationship of the variables in the study location. The mean was used to determine the average distribution of the variables. Soil properties were assessed for their variability using coefficient of variation $(\% \mathrm{CV})$ and compared with variability classes proposed by Tabi and Ogunkunle (2007) where CV values of $0-15,16-35$ and $>35 \%$ are rated as slight, moderate, and high respectively.

\section{RESULTS AND DISCUSSION}

\section{Morphological Properties of the Pedons}

The details of the morphological properties of the pedons are shown in Table 2. Pedons 1 and 2 were characterized by dark brown colour $(7.5 \mathrm{YR} 6 / 3)$ at the surface and varying colour at the subsurface horizons. Pedon 1 has yellow mottles (10YR7/8) in the $\mathrm{B}_{\mathrm{t}}$ horizon. Rock boulder was present in the $\mathrm{B}_{\mathrm{r}}$ horizon. The soil colour matrix of pedon 3 ranged from yellow brown $(7.5 \mathrm{YR} 4 / 3)$ at the surface to yellow (5YR4/8) in the subsurface. In terms of soil structure, consistency and horizon boundary, the pedons differ from one another. The soil texture was sandy loam at the surface and loamy sand to sandy clay at the subsurface. Soil texture has been reported to directly influence the moisture status of lowland rice soils (Obalum et al., 2011). It influences soil permeability and hence soil moisture redistribution and water holding capacity (Ogban, 2017).

\section{Physical Properties of the Pedons}

Table 3 shows the physical properties of the soils. In Pedon 1, gravel content varied between 20.3 and $66.7 \mathrm{~g} / \mathrm{kg}$. Sand dominates the particle sizes and fluctuates within the profile. The clay content in the $\mathrm{B}_{\mathrm{t}}$ horizon of the pedon 1 increased by $454 \mathrm{~g} / \mathrm{kg}$, and this might be as a result of clay migration by lessivage. In pedons 2 and 3 , there is a uniform distribution of sand and clay fractions. Low clay content in pedon 2 could be due to erosion and in pedon 3 as a result of seasonal waterlogging which could hinder pedogenic processes and loss of clay when the soils are flooded during the rainy season (Akpan-Idiok et al., 2004). Silt content was high in pedon 3 and varied from 88 to $248 \mathrm{~g} / \mathrm{kg}$. This is a pointer to the stage of development of the soils. The result was similar to that of the result reported by Aiboni (2001). The bulk density of the soils ranged from 1.18 to $1.55 \mathrm{~g} / \mathrm{cm}^{3}$ and fluctuated with increasing depth.

\begin{tabular}{|c|c|c|c|c|c|c|c|c|}
\hline $\begin{array}{l}\text { Horizon } \\
\text { Designation }\end{array}$ & $\begin{array}{l}\text { Depth } \\
(\mathrm{cm})\end{array}$ & $\begin{array}{c}\text { Slope } \\
(\%)\end{array}$ & $\begin{array}{l}\text { Colour } \\
\text { Matrix }\end{array}$ & Structure & Consistency & Boundary & Drainage & $\begin{array}{c}\text { Mottles } \\
\text { Concretions }\end{array}$ \\
\hline \multicolumn{9}{|c|}{ Pedon 01 (Egbeda Series) } \\
\hline$A_{p}$ & $0-12$ & 3 & $7.5 \mathrm{YR} 6 / 3, \mathrm{db}$ & w, me, gr & ns, fr & $\mathrm{sm}, \mathrm{cl}$ & Wd & $\mathrm{N}$ \\
\hline $\mathrm{AB}$ & $12-27$ & & $7.5 \mathrm{YR} 4 / 3, \mathrm{~b}$ & $\mathrm{w}, \mathrm{me}, \mathrm{gr}$ & ns, fr & $\mathrm{sm}, \mathrm{cl}$ & $\mathrm{Wd}$ & $\mathrm{N}$ \\
\hline $\mathrm{B}_{\mathrm{r}}$ & $27-48$ & & 7.5YR6/5, ry & $\mathrm{m}, \mathrm{me}, \mathrm{sab}$ & ns, fr & $\mathrm{sm}, \mathrm{cl}$ & Wd & $\mathrm{f}, \mathrm{vm}$ \\
\hline $\mathrm{B}_{\mathrm{t}}$ & $48-76$ & & $2.5 \mathrm{YR} 4 / 8, \mathrm{r}$ & $\mathrm{m}, \mathrm{co}, \mathrm{sab}$ & vs, fm & wv, ab & Wd & $\mathrm{N}$ \\
\hline $\mathrm{BC}$ & $76-114$ & & $2.5 \mathrm{YR} 3 / 6, \mathrm{dr}$ & $\mathrm{s}, \mathrm{co}, \mathrm{b}$ & $\mathrm{ss}, \mathrm{fm}$ & - & $\mathrm{Wd}$ & $\mathrm{N}$ \\
\hline \multicolumn{9}{|c|}{ Pedon 02 (Apomu Series) } \\
\hline $\mathrm{A}_{\mathrm{p}}$ & $0-18$ & 2 & $7.5 \mathrm{YR} 6 / 3, \mathrm{db}$ & $\mathrm{w}, \mathrm{f}, \mathrm{cr}$ & ns, lo & $\mathrm{sm}, \mathrm{cl}$ & Wd & $\mathrm{N}$ \\
\hline $\mathrm{AB}$ & $18-30$ & & $7.5 \mathrm{YR} 6 / 3, \mathrm{db}$ & w, me, sab & ns, fr & ir, cl & $\mathrm{Wd}$ & $\mathrm{N}$ \\
\hline $\mathrm{B}_{\mathrm{t}}$ & $30-48$ & & $7.5 \mathrm{YR} 4 / 3, \mathrm{~b}$ & $\mathrm{~m}, \mathrm{me}, \mathrm{sab}$ & $\mathrm{ns}$, fr & $\mathrm{sm}, \mathrm{cl}$ & $\mathrm{Wd}$ & $\mathrm{f}, \mathrm{fe}$ \\
\hline $\mathrm{B}_{\mathrm{s}}$ & $48-82$ & & $2.5 \mathrm{YR} 3 / 6, \mathrm{dr}$ & $\mathrm{m}, \mathrm{co}, \mathrm{sab}$ & ss, fm & $w v, d f$ & Wd & $\mathrm{f}, \mathrm{vm}$ \\
\hline $\mathrm{B}_{\mathrm{t}}$ & $82-118$ & & $5 \mathrm{YR} 5 / 4, \mathrm{rb}$ & $\mathrm{s}, \mathrm{me}, \mathrm{sab}$ & $\mathrm{ss}, \mathrm{fm}$ & - & Wd & $\mathrm{N}$ \\
\hline \multicolumn{9}{|c|}{ Pedon 03 (Ikire Series) } \\
\hline A & $0-20$ & 2 & 7.5YR4/3, yb & $\mathrm{w}, \mathrm{me}, \mathrm{gr}$ & $\mathrm{ns}$, fr & $\mathrm{sm}, \mathrm{cl}$ & $\mathrm{Pd}$ & $\mathrm{N}$ \\
\hline $\mathrm{AB}$ & $20-46$ & & 7.5YR4/3, yb & w, me, gr & ns, lo & $\mathrm{sm}, \mathrm{cl}$ & $\mathrm{Pd}$ & $\mathrm{N}$ \\
\hline $\mathrm{B}_{\mathrm{t}}$ & $46-62$ & & 10YR6/3, dy & $\mathrm{m}, \mathrm{me}, \mathrm{sab}$ & ss, fr & ir, di & $\mathrm{Pd}$ & $\mathrm{N}$ \\
\hline $\mathrm{B}_{\mathrm{t}}$ & $62-76$ & & $5 \mathrm{YR} 4 / 8, \mathrm{y}$ & $\mathrm{m}, \mathrm{me}, \mathrm{sab}$ & ss, fm & - & $\mathrm{Pd}$ & $\mathrm{N}$ \\
\hline
\end{tabular}

Table 2: Morphological properties of soils of Alabata

Structure: w - weak, m - moderate, s - strong, f - fine, me - medium, co - coarse, cr - crumb, gr - granular, sab - sub-angular blocky, b - blocky. Consistency: ns - non-sticky, ss - slightly sticky, s - sticky, vs - very sticky, lo - loose, fm - firm, fr - friable, vf - very firm. Boundary: sm - smooth, wv - wavy, ir - irregular, ab - abrupt, cl - clear, di - diffuse. Mottle Concretions: $\mathrm{n}$ - none, f - few, fe - fine, vm - very many. Drainage: wd - well drained, pd - poorly drained 


\section{Chemical Properties of the Soils}

The results on chemical properties of the soils are presented in Table 4 . The soil reactions were strongly acidic to slightly acidic ( $\mathrm{pH}$ 5.0-6.1 and 4.2-5.6 for water and $\mathrm{KCl}$, respectively), and varied between the pedons. Acidification or lowering of soil $\mathrm{pH}$ has negative impacts on most crop growth (Horneck et al., 2011). Organic carbon content was low $(5.6-19.0 \mathrm{~g} / \mathrm{kg}$ ) as values are below $45 \mathrm{~g} / \mathrm{kg}$ regarded for productive soils (Holland et al., 1989). The organic matter $(\mathrm{OM})$ content of the soils ranged between 9.7 and $32.9 \mathrm{~g} / \mathrm{kg}$ with the highest value recorded in the surface soil of pedon 2. This was attributed to the accumulation of plant litters, leaves, stems, and erosion deposit from the upper slope. The total nitrogen $(\mathrm{TN})$ values were low $(0.6-1.7 \mathrm{~g} / \mathrm{kg})$ as all the values were below $4.5 \mathrm{~g} / \mathrm{kg}$ established for productive soils (Federal Fertilizer Department, FFD, 2012). The low content could be ascribed to rapid microbial activities and crop removal, leading to nitrate loss in the soil environment (Aiboni et al., 2007). This is an obvious reason to expect a decreased level of the nitrogen content of the soil as $\mathrm{OM}$ is essentially the main source of nitrogen.

Table 3: Physical properties of soils of Alabata

\begin{tabular}{|c|c|c|c|c|c|c|c|c|c|}
\hline \multirow{2}{*}{$\begin{array}{l}\text { Horizon } \\
\text { Designation }\end{array}$} & \multirow{2}{*}{$\begin{array}{l}\text { Depth } \\
(\mathrm{cm})\end{array}$} & \multirow{2}{*}{$\begin{array}{c}\text { Slope } \\
(\%)\end{array}$} & Gravel & Sand & Silt & Clay & \multirow{2}{*}{$\begin{array}{l}\text { Bulk density } \\
\left(\mathrm{g} / \mathrm{cm}^{3}\right)\end{array}$} & \multirow{2}{*}{$\begin{array}{c}\text { Porosity } \\
(\%)\end{array}$} & \multirow{2}{*}{$\begin{array}{c}\text { Textural } \\
\text { Class }\end{array}$} \\
\hline & & & \multicolumn{4}{|c|}{$\mathrm{g} / \mathrm{kg}$} & & & \\
\hline \multicolumn{10}{|c|}{ Pedon 01 (Egbeda Series) } \\
\hline Ap & $0-12$ & 3 & 203 & 858 & 68 & 74 & 1.54 & 41.9 & Loamy sand \\
\hline $\mathrm{AB}$ & $12-27$ & & 375 & 818 & 88 & 94 & 1.52 & 42.6 & Loamy sand \\
\hline $\mathrm{B}_{\mathrm{r}}$ & $27-48$ & & 667 & 818 & 68 & 114 & 1.51 & 43.0 & Sandy loam \\
\hline $\mathrm{B}_{\mathrm{t}}$ & $48-76$ & & 612 & 458 & 88 & 454 & 1.18 & 55.5 & Sandy clay \\
\hline \multirow[t]{2}{*}{$\mathrm{BC}$} & $76-114$ & & 644 & 678 & 148 & 174 & 1.47 & 44.5 & Sandy loam \\
\hline & Mean & & 500 & 726 & 92 & 182 & 1.44 & 45.5 & \\
\hline \multicolumn{10}{|c|}{ Pedon 02 (Apomu Series) } \\
\hline Ap & $0-18$ & 2 & 217 & 858 & 68 & 74 & 1.55 & 41.5 & Loamy sand \\
\hline $\mathrm{AB}$ & $18-30$ & & 243 & 818 & 88 & 94 & 1.53 & 42.3 & Loamy sand \\
\hline $\mathrm{B}_{\mathrm{t} 1}$ & $30-48$ & & 431 & 778 & 88 & 134 & 1.50 & 43.4 & Sandy loam \\
\hline $\mathrm{B}_{\mathrm{s}}$ & $48-82$ & & 623 & 758 & 88 & 154 & 1.48 & 44.2 & Sandy loam \\
\hline \multirow[t]{2}{*}{$\mathrm{B}_{\mathrm{t} 2}$} & $82-118$ & & 606 & 638 & 88 & 274 & 1.41 & 46.8 & Sandy clay loam \\
\hline & Mean & & 424 & 770 & 84 & 146 & 1.49 & 43.6 & \\
\hline \multicolumn{10}{|c|}{ Pedon 03 (Ikire Series) } \\
\hline A & $0-20$ & 2 & 610 & 798 & 88 & 114 & 1.50 & 43.4 & Sandy loam \\
\hline $\mathrm{AB}$ & $20-46$ & & 205 & 818 & 68 & 114 & 1.51 & 43.0 & Loamy sand \\
\hline $\mathrm{B}_{\mathrm{t} 1}$ & $46-62$ & & 147 & 758 & 108 & 134 & 1.49 & 43.8 & Sandy loam \\
\hline \multirow[t]{3}{*}{$\mathrm{B}_{\mathrm{t} 2}$} & $62-76$ & & 125 & 678 & 148 & 174 & 1.46 & 44.9 & Sandy loam \\
\hline & Mean & & 135 & 766 & 103 & 134 & 1.49 & 43.8 & \\
\hline & $\% \mathrm{CV}$ & & 60.5 & 14.4 & 28.4 & 64.5 & 08.7 & 09.2 & \\
\hline
\end{tabular}

Table 4: Chemical properties of soils of Alabata

\begin{tabular}{|c|c|c|c|c|c|c|c|c|c|c|c|c|c|c|}
\hline \multirow[t]{2}{*}{$\begin{array}{l}\text { Horizon } \\
\text { Designation }\end{array}$} & \multirow[t]{2}{*}{$\begin{array}{l}\text { Depth } \\
(\mathrm{cm})\end{array}$} & \multirow[t]{2}{*}{$\begin{array}{l}\mathrm{pH}- \\
\mathrm{H}_{2} \mathrm{O}\end{array}$} & \multirow[t]{2}{*}{$\begin{array}{l}\mathrm{pH}- \\
\mathrm{KCl}\end{array}$} & $\mathrm{OC}$ & $\mathrm{OM}$ & $\mathrm{TN}$ & \multirow{2}{*}{$\begin{array}{c}\text { Avail. } \\
\text { P } \\
(\mathrm{mg} / \mathrm{kg})\end{array}$} & $\mathrm{Na}^{+}$ & $\mathrm{K}^{+}$ & $\mathrm{Ca}^{2+}$ & $\mathrm{Mg}^{2+}$ & $\begin{array}{l}\mathrm{Al}^{3+} \\
+\mathrm{H}^{+}\end{array}$ & ECEC & \multirow{2}{*}{$\begin{array}{l}\text { BS } \\
(\%)\end{array}$} \\
\hline & & & & & $(\mathrm{g} / \mathrm{kg})$ & & & \multicolumn{6}{|c|}{$(\mathrm{cmol} / \mathrm{kg})$} & \\
\hline \multicolumn{15}{|c|}{ Pedon 01 (Egbeda Series) } \\
\hline Ap & $0-12$ & 6.0 & 5.2 & 17.6 & 30.4 & 1.1 & 4.47 & 0.10 & 0.37 & 0.57 & 1.11 & 0.3 & 2.45 & 87.7 \\
\hline $\mathrm{AB}$ & $12-27$ & 5.7 & 5.0 & 11.8 & 20.4 & 0.8 & 4.10 & 0.09 & 0.33 & 0.69 & 1.12 & 0.9 & 3.13 & 71.3 \\
\hline $\mathrm{B}_{\mathrm{r}}$ & $27-48$ & 6.1 & 5.6 & 11.9 & 20.6 & 0.9 & 4.17 & 0.14 & 0.47 & 0.65 & 1.12 & 0.5 & 2.88 & 82.6 \\
\hline $\mathrm{B}_{\mathrm{t}}$ & $48-76$ & 5.7 & 4.8 & 11.7 & 20.2 & 0.7 & 3.59 & 0.11 & 0.34 & 0.59 & 1.10 & 0.7 & 2.84 & 75.4 \\
\hline \multirow[t]{2}{*}{$\mathrm{BC}$} & $76-114$ & 5.2 & 4.4 & 11.4 & 19.7 & 0.5 & 3.23 & 0.09 & 0.39 & 0.61 & 1.13 & 0.4 & 2.62 & 84.7 \\
\hline & Mean & 5.74 & 5.00 & 12.9 & 22.3 & 0.8 & 3.91 & 0.11 & 0.38 & 0.62 & 1.12 & 0.56 & 2.78 & 80.3 \\
\hline \multicolumn{15}{|c|}{ Pedon 02 (Apomu Series) } \\
\hline Ap & $0-18$ & 5.9 & 5.2 & 19.0 & 32.9 & 1.7 & 3.90 & 0.09 & 0.33 & 0.49 & 1.13 & 0.4 & 2.44 & 83.6 \\
\hline $\mathrm{AB}$ & $18-30$ & 5.3 & 4.8 & 18.0 & 31.1 & 1.1 & 3.61 & 0.07 & 0.25 & 0.55 & 1.12 & 0.3 & 2.29 & 86.9 \\
\hline $\mathrm{B}_{\mathrm{t} 1}$ & $30-48$ & 5.0 & 4.2 & 13.2 & 22.8 & 0.8 & 3.37 & 0.10 & 0.39 & 0.70 & 1.14 & 0.5 & 2.83 & 89.4 \\
\hline $\mathrm{B}_{\mathrm{s}}$ & $48-82$ & 5.1 & 4.4 & 12.8 & 22.1 & 0.8 & 3.42 & 0.09 & 0.31 & 0.60 & 0.95 & 0.4 & 2.35 & 83.0 \\
\hline \multirow[t]{3}{*}{$\mathrm{B}_{\mathrm{t} 22}$} & $82-118$ & 5.2 & 4.8 & 11.6 & 20.1 & 0.7 & 2.88 & 0.09 & 0.30 & 0.66 & 0.96 & 0.3 & 2.31 & 87.0 \\
\hline & Mean & 5.30 & 4.68 & 14.9 & 25.8 & 1.0 & 3.44 & 0.09 & 0.32 & 0.60 & 1.06 & 0.38 & 2.45 & 86.0 \\
\hline & \multicolumn{14}{|c|}{ Pedon 03 (Ikire Series) } \\
\hline A & $0-20$ & 5.8 & 5.0 & 8.9 & 15.4 & 1.3 & 4.41 & 0.09 & 0.34 & 0.50 & 1.10 & 0.5 & 2.53 & 80.3 \\
\hline $\mathrm{AB}$ & $20-46$ & 5.7 & 5.2 & 8.0 & 13.8 & 0.8 & 3.62 & 0.09 & 0.30 & 0.69 & 1.12 & 0.3 & 2.50 & 88.0 \\
\hline $\mathrm{B}_{\mathrm{t} 1}$ & $46-62$ & 5.6 & 4.8 & 7.0 & 12.1 & 0.8 & 4.11 & 0.09 & 0.28 & 0.57 & 0.11 & 0.3 & 2.35 & 87.2 \\
\hline \multirow[t]{3}{*}{$\mathrm{B}_{\mathrm{t} 2}$} & $62-76$ & 5.4 & 4.6 & 5.6 & 9.7 & 0.6 & 2.15 & 0.11 & 0.44 & 0.63 & 0.99 & 0.6 & 2.77 & 78.3 \\
\hline & Mean & 5.63 & 4.90 & 7.4 & 12.8 & 0.9 & 3.57 & 0.10 & 0.34 & 0.60 & 1.08 & 0.43 & 2.54 & 83.5 \\
\hline & $\% \mathrm{CV}$ & 06.3 & 07.8 & 33.6 & 33.5 & 31.9 & 17.3 & 16.0 & 17.5 & 11.1 & 06.1 & 38.8 & 10.0 & 06.4 \\
\hline
\end{tabular}

OC - organic carbon, OM - organic matter, TN - total nitrogen, Avail. P - available phosphorus,

ECEC - effective cation exchange capacity, BS - base saturation 
Available phosphorus was low (2.15-4.47 mg/kg) as the values are less than $5.0 \mathrm{mg} / \mathrm{kg}$ in all the soils (Hazelton and Murphy, 2007). The situation could be accounted for by the strong acidic condition of the soil which could enhance the P-fixation in the soils. Also the parent materials of the soils could be poor in phosphorus minerals (Aiboni, 2001). The exchangeable bases and acidity values were low; $\mathrm{Ca}(0.5-0.7 \mathrm{cmol} / \mathrm{kg}), \mathrm{Mg}(0.95-1.43 \mathrm{cmol} / \mathrm{kg})$, $\mathrm{Na}(0.09-0.14 \mathrm{cmol} / \mathrm{kg}), \mathrm{K}(0.25-0.47 \mathrm{cmol} / \mathrm{kg})$, and $\mathrm{Al}+\mathrm{H}(0.3-0.9 \mathrm{cmol} / \mathrm{kg})$. The ECEC of the soils were generally low $(2.29-3.13 \mathrm{cmol} / \mathrm{kg})$, as values were less than $10 \mathrm{cmol} / \mathrm{kg}$ (FFD, 2012). This observation could be connected to the presence of low activity clays in the area (Aiboni, 2001), as well as to the low levels of organic matter in the soils (Obalum et al., 2012). The depletion of OM as a result of continuous cultivation could result in reduced CEC in these soils. In line with the previous observations in the basement complex area, the soils have an argillic horizon and high base saturation (71.3-88.0\%) which is probably associated with the presence of weatherable minerals in the soil profiles and inadequate leaching caused by several dry months. With the mean base saturation values above $80 \%$, basic nutrients might exist in available form in the soil solution despite the low basic cation reserves in the soils.

\section{Variability of Soils of the Toposequence}

The coefficient of variation (\% CV) which is known to normalize variability was also reported to enable comparison of the soil physicochemical properties regarding the extent of variability. Among the selected physical properties, the variability was slight for sand, bulk density and total porosity, it was moderate for silt, and high for gravel and clay content. Similar results have been reported by other researchers across various landscapes in the West-African savanna (Tabi and Ogunkunle, 2007; Tabi et al., 2012; Obalum et al., 2013; Asongwe et al., 2016). Soil pH $\left(\mathrm{H}_{2} \mathrm{O}\right.$ and $\left.\mathrm{KCl}\right), \mathrm{Ca}, \mathrm{Mg}, \mathrm{ECEC}$, and base saturation were slightly variable; organic matter, TN, available $\mathrm{P}, \mathrm{Na}, \mathrm{K}$ and $\mathrm{Al}^{3+}+\mathrm{H}^{+}$were moderately to highly variable. The variability of soil chemical properties is similar to that reported by Tabi and Ogunkunle (2007) for Alfisols in Southern Nigeria. The ECEC and base saturation which is equally slightly variable reflects $\mathrm{pH}$ variability (Asongwe et al., 2016).

\section{Classification of Soils of the Toposequence}

Generally, all the pedons showed consistently increasing clay with soil depth and are therefore argillic. They are characterized by high base saturation $>50 \%$ by CEC determined at pH 7.0 (NH4OAc), and low CEC $(<16 \mathrm{cmol} / \mathrm{kg})$. The pedons are well developed with distinct diagnostic horizons and the brown to reddish soil colour are the basis they have been classified as Alfisols (Soil Survey Staff, 2014). The prevalent Ustic moisture regime in these soils classified them into the sub-order Ustalfs (Soil Survey Staff, 2014). The hue of 7.5YR with chroma of 5 or more placed them in the great group Paleustalfs, and the CEC $<24 \mathrm{cmol} / \mathrm{kg}$ indicating low-activity clay are the basis for classifying them into subgroup Kandic (Soil Survey Staff, 2014).

However, the foot slope pedon where the water table is near the surface during a considerable part of the year but drops latter in the year placed in the sub-order Aqualfs and great group Kandiaqualfs due to very low CEC (Soil Survey Staff, 2014). The Hue of 10 YR or yellower and both a colour value and chroma of 3 or more (moist and dry) with no redox concentrations placed them in sub-group Aeric (Soil Survey Staff, 2014). The corresponding FAO-UNESCO (2015) classifications are provided. At the local series level, the pedons have been classified as Egbeda, Apomu and Ikire series (Table 5) according to Smyth and Montgomery (1962) soil classification system based on the concentration of sand, silt and clay contents.

\section{Soil Suitability Evaluation for Rice Production}

The climatic conditions of the study area are rated as $\mathrm{S} 11$ in term of rainfall, temperature and relative humidity (Table 6). This is because the mean annual rainfall in the range of 1000-1200 $\mathrm{mm}$ is considered to be relatively adequate. The slope, drainage, and flooding condition of the pedons vary and are rated as $\mathrm{S} 11, \mathrm{~S} 12$ and $\mathrm{S} 2$ respectively. The average soil rooting depth in pedons 1 and 2 was greater than $100 \mathrm{~cm}$ and were rated S11 while, pedon 3 was rated $\mathrm{S} 12$ being less than $100 \mathrm{~cm}$ in depth. The textural classes of the soils which include sandy loam in the surface horizons to sandy clay loam, sandy clay or clay in the subsurface horizons is rate as $\mathrm{S} 3$ for pedons 1 and 2 while pedon 3 rated as S2. In terms of gravel content all the pedons were rated as S11. Apart from the base saturation which was high and rated as S11, all the other fertility requirements considered for this evaluation were sub-optimal and were rated between S2 and S3. The most limiting fertility parameter was the CEC which was rated as N1 in all the pedons.

Cumulatively, the aggregate actual suitability class of all the pedons by the linear parametric was $\mathrm{N} 2$ while square root model was $\mathrm{N} 1$, suggesting that the soils were currently not suitable for rice production (Tables 7 and 8). However, the productivity of the soils could be improved with adequate application of the Appropriate type of fertilizers (both organic and Inorganic). The potential suitability which is a reflection of what is expected after good soil fertility management was moderate (S2) for pedons 1 and 2 as computed by the two models (Linear and Square root models) except for pedon 3 which is S3 by the linear computation. The results are also similar to the work of Ajiboye et al. (2011). This is an indication that the soils are potentially marginally to moderately suitable for rice production. Thus, the fertility status of these soils needs an amendment to improve the productive capacity of the soils into those that are highly suitable for rice production. 
Table 5: Taxonomic classification of soils of the toposequence

\begin{tabular}{lllll}
\hline Pedon & Slope Location & Soil Survey Staff (2014) & FAO-UNESCO (2015) & Local Series Name \\
\hline 01 & Upper Slope & Kandic Paleustalfs & Ferric Lixisols & Egbeda \\
02 & Middle Slope & Typic Haplustalfs & Eutric Lixisols & Apomu \\
03 & Valley Bottom & Aeric Kandiaqualfs & EutricLuvisols & Ikire \\
\hline
\end{tabular}

Table 6: Suitability evaluation of the soils for rice production

\begin{tabular}{|c|c|c|c|c|}
\hline Land Qualities & & Pedon 1 & Pedon 2 & Pedon 3 \\
\hline \multirow[t]{4}{*}{ Climate (C) } & Annual rainfall $(\mathrm{mm})$ & $100(\mathrm{~S} 11)$ & $100(\mathrm{~S} 11)$ & $100(\mathrm{~S} 11)$ \\
\hline & No. of dry months & 95 (S12) & 95 (S12) & 95 (S12) \\
\hline & Mean annual temperature $\left({ }^{\circ} \mathrm{C}\right)$ & $100(\mathrm{~S} 11)$ & $100(\mathrm{~S} 11)$ & $100(\mathrm{~S} 11)$ \\
\hline & Relative humidity (\%) & $100(\mathrm{~S} 11)$ & $100(\mathrm{~S} 11)$ & $100(\mathrm{~S} 11)$ \\
\hline Topography (T) & Slope gradient $(\%)$ & $100(\mathrm{~S} 12)$ & $100(\mathrm{~S} 11)$ & $100(\mathrm{~S} 11)$ \\
\hline \multirow[t]{2}{*}{ Wetness (W) } & Drainage & $100(\mathrm{~S} 11)$ & $100(\mathrm{~S} 11)$ & $60(\mathrm{~S} 3)$ \\
\hline & Flooding & $100(\mathrm{~S} 11)$ & $100(\mathrm{~S} 11)$ & $85(\mathrm{~S} 2)$ \\
\hline \multirow[t]{3}{*}{ Soil physical properties (S) } & Soil depth (cm) & $100(\mathrm{~S} 11)$ & $100(\mathrm{~S} 11)$ & 95 (S12) \\
\hline & Surface texture & $60(\mathrm{~S} 3)$ & $60(\mathrm{~S} 3)$ & $85(\mathrm{~S} 2)$ \\
\hline & Gravel at $0-20 \mathrm{~cm}(\%)$ & $60(\mathrm{~S} 3)$ & $60(\mathrm{~S} 3)$ & $85(\mathrm{~S} 2)$ \\
\hline \multirow[t]{11}{*}{ Chemical fertility (F) } & $\mathrm{pH}$ in distilled water & $70(\mathrm{~S} 2)$ & $60(\mathrm{~S} 3)$ & $65(\mathrm{~S} 2)$ \\
\hline & Organic matter $(\%)$ & $80(\mathrm{~S} 2)$ & $80(\mathrm{~S} 2)$ & $65(\mathrm{~S} 2)$ \\
\hline & Total nitrogen (\%) & $70(\mathrm{~S} 2)$ & $70(\mathrm{~S} 2)$ & $70(\mathrm{~S} 2)$ \\
\hline & Available P (mg/kg) & $60(\mathrm{~S} 3)$ & $55(\mathrm{~S} 3)$ & $60(\mathrm{~S} 3)$ \\
\hline & Exchange $\mathrm{K}(\mathrm{cmol} / \mathrm{kg})$ & $85(\mathrm{~S} 2)$ & $80(\mathrm{~S} 2)$ & $85(\mathrm{~S} 2)$ \\
\hline & Cation exchange capacity $(\mathrm{cmol} / \mathrm{kg})$ & $30(\mathrm{~N} 1)$ & $30(\mathrm{~N} 1)$ & $30(\mathrm{~N} 1)$ \\
\hline & Base saturation (\%) & $100(\mathrm{~S} 11)$ & $100(\mathrm{~S} 11)$ & $100(\mathrm{~S} 11)$ \\
\hline & Actual suitability (linear) & $10.3(\mathrm{~N} 2)$ & 9.4 (N2) & 8.7 (N2) \\
\hline & Actual suitability (square root) & $17.5(\mathrm{~N} 1)$ & $16.8(\mathrm{~N} 1)$ & $16.2(\mathrm{~N} 1)$ \\
\hline & Potential suitability (linear) & $57.0(\mathrm{~S} 2)$ & $57.0(\mathrm{~S} 2)$ & $48.5(\mathrm{~S} 3)$ \\
\hline & Potential suitability (square root) & $58.5(\mathrm{~S} 2)$ & $58.5(\mathrm{~S} 2)$ & $53.9(\mathrm{~S} 2)$ \\
\hline
\end{tabular}

S1 - highly suitable, S2 - moderately suitable, S3 - marginally suitable; N1 - currently not suitable; N2 - permanently not suitable

\section{CONCLUSION}

Classification and suitability evaluation of rice soils helps to identify production constraints and prospects. Alabata environment is only marginally to moderately suitable for rice production despite its near-optimal climate. The slope, soil wetness, organic carbon and potassium contents are highly suitable. The major constraints to optimum performance of rice are soil texture and some chemical fertility (N, P, and CEC). Emphasis should be on management techniques that will enhance nutrient and moisture holding capacities of these soils. Fertilizers having an appreciable amount of $\mathrm{CaO}$ and $\mathrm{MgO}$ in addition to the recommended rate of $\mathrm{N}, \mathrm{P}, \mathrm{K}$ for low fertility soils will be of utmost benefit to rice production in this area. Use of organic materials such as plant refuse to conserve moisture and supply nutrients is valuable in these respects.

\section{REFERENCES}

AbdelRahman M.A.E., Natarajan A. and Hegde R. (2016). Assessment of land suitability and capability by integrating remote sensing and GIS techniques in Chamarajanagar District, Karnataka, India. Egyptian J. Rem. Sens. Space Sci., 19, 125-141
Addeo G., Guastadisegni G. and Pisante M. (2001). Land and water quality for sustainable and precision farming. $1^{\text {st }}$ World Cong. Conserv. Agric., Madrid, Spain, 1-5 Oct., 2001, pp. 1-4

Aiboni V.U. (2001). Characteristics and classification of soils of a representative topography location in UNAAB. ASSET Series A, 1 (1),35-50

Aiboni V.U., Okeleye K.A. and Adeniji I.A. (2007). Potential of lowland rice under improved soil management in farmer's plot at Odeda, Southwestern Nigeria. J. Agric. Sci. Environ., 7 (1), 15-22

Ajala A.S. and Gana A. (2015). Analysis of challenges facing rice processing in Nigeria. J. Food Processing, 6, 1-6

Ajiboye G.A., Alabi K.O., Adesodun J.K. \& Aiboni V.U. (2011). Classification and suitability evaluation of the soils of a toposequence at Odeda, Ogun State for the production of rice (Oryza sativa). Nigerian J. Soil Sci., 21 (2), 142-155

Akande T. (2003). An overview of the Nigeria rice economy. Nigeria Inst. Soc. Econ. Res., Nigeria. USDA Int. Database

Akpan-Idiok A.U., Esu I.E. and Etim V.J. (2004). Characteristics and classification of basaltic soils on a toposequence in Southeast, Nigeria. Proc. 29 $9^{\text {th }}$ Annual Conf. Soil Sci. Soc. Nigeria. Dec. 6-10, 2004. University of Agriculture, Abeokuta, pp. 64-70 
Ana R. (2010). Impact of Climate Change on Rice Production. Digitals Ltd. Istanbul

Asongwe G.A., Yerima B.P.K. and Tening A.S. (2016). Spatial variability of selected physicochemical properties of soils under vegetable cultivation in urban and peri-urban wetland gardens of Bamenda municipality, Cameroon. Afr. J. Agric. Res., 11 (2), 74-86

Bray R.H. and Kurtz L.T. (1945). Determination of total organic and available forms of phosphorus in soils. Soil Sci., 59, 22-29

Bremmer J.M. and Mulvaney C.S. (1982). Total nitrogen. In: Page A.L., Miller R.H. and Keeney D.R. (eds.), Methods of Soil Analysis. Madison, WI: American Society of Agronomy, 2, 149-158

FAO (2006). Guideline for Soil Description. 4th ed. FAO, Rome. 109 pp.

FAO (2007). Land evaluation towards a revised framework. Land and Water Discussion Paper 6. FAO, Rome

FAO/UNESCO (2015). World Reference Base for Soil Resources 2014. International Soil Classification System for Naming Soils and Creating Legends for Soil Maps. FAO, Rome, 203 pp.

FAO (2019). Nigeria at a glance. Retrieved from: http:// www.fao.org/nigeria/fao-in-nigeria/nigeria-at-aglance/en/

FAOSTAT (2018). Food and agricultural data for Nigeria. http://www.fao.org $>$ faostat. Accessed 05/08/2018

Fasina A.S. and Adeyanju A. (2007). Comparison of three land evaluation systems in evaluating the predictive value of some selected soils in Ado-Ekiti, Southwest Nigeria. J. Soil Sci., 17,113-119

Federal Fertilizer Department (2012). Fertilizer Use and Management Practices for Crop Production in Nigeria (4th ed). Chude V.O. et al. (eds.), Fed. Min. Agric. Rural Dev., Abuja, Nigeria. ISSN 115-554X

FUNAAB. (2018). Record of daily agrometeorological observation. Department of Water Resources Management \& Agrometeorology, College of Environmental Management, Federal University of Agriculture, Abeokuta, pp 1-12

Gee G. and Bauder J.W. (1986). Particle size analysis. In: Klute A. (eds.). Methods of Soil Analysis. Madison WI: American Society of Agronomy, 1, 91-100

Hazelton P. and Murphy B. (2007). Interpreting Soil Test Results: What Do All the Numbers Mean? 2nd ed. 152 pp. (CSIRO Publishing)

Holland M.D., Allen R.K.G., Barten D. and Murphy S.T. (1989). Land evaluation and agricultural development for Cross River national park, Oban Division. Prepared by Overseas Dev. National Resources Inst. and WWF for the Federal Republic of Nigeria and Cross-River State Government, p. 1189

Horneck D.A., Sullivan D.M., Owen J.S. and Hart J.M. (2011). Soil test interpretation guide. Oregon State University, $12 \mathrm{pp}$.

IITA (1982). Selected Methods for Soil and Plant Analysis. Int. Inst. Trop. Agric. Manual Series, 1, 70

Jagdish P., Ray S.K., Gajbhiye K.S. and Singh S.R. (2009). Soil of Selsura research farm in Wardha District, Maharashtra and their suitability for crops. Agroped., 19 (2), 84-91

Logan T.J. and Harrison B.J. (1995). Physical characteristics of alkaline stabilized sewage sludge (Nviro soil) and their effects on soil physical properties. J. Envtal. Qual., 24, 153-164
Meena H.B., Giri J.D. and Mishra H.K. (2009). Suitability assessment of soils occurring on different landforms of Chittorgarh District, Rajasthan. Agroped., 19 (2), 75-83

Murphy J. and Riley J.P. (1962). A modified single solution method for the determination of phosphate in natural waters. Anal Chem. Acta., 27, 31-36

Mustafa A.A., Man S., Sahoo R.N., et al. (2011). Land suitability analysis for different crops. A multi criteria decision making approach using remote sensing and GIS. Indian Agricultural Research Institute, New Delhi-110 012

Obalum S.E., Nwite J.C., Oppong J., Igwe C.A. and Wakatsuki T. (2011). Variations in selected soil physical properties with landforms and slope within an inland valley ecosystem in Ashanti Region of Ghana. Soil Water Res., 6 (2), 73-82

Obalum S.E., Nwite J.C., Watanabe Y., Igwe C.A. and Wakatsuki T. (2012). Comparative topsoil characterization of sawah rice fields in selected inland valleys around Bida, north-central Nigeria: physicochemical properties and fertility status. Trop. Agric. Dev., 56 (2), 39-48

Obalum S.E., Oppong J., Igwe C.A., Watanabe Y. and Obi M.E. (2013). Spatial variability of uncultivated soils in derived savanna. Int. Agrophys., 27, 57-67

Ogban P.I. (2017). Effect of land use on infiltration characteristics of soils in Northern Akwa Ibom State, South Eastern Nigeria. Agro-Sci., 16 (3), 29-36

Sathish A. and Niranjana K.V. (2010). Land suitability studies for major crops in Pavagadataluk, Karnataka using remote sensing and GIS techniques. J. Indian Soc. Rem. Sens., 38 (1), 143-151

Smyth A.J. and Montgomery R.F. (1962). Soils and Land Use in Central Western Nigeria. Government Printer, Ibadan, p. 264

Singh T.B., Devi K.D., Kumar Y.B., Bishworjit N., Singh L.N.K. and Singh A.H. (2013). Characterization and evaluation for crop suitability in lateritic soils. Afr. J. Agric. Res., 8 (37), 4628-4636

Soil Survey Staff. (2014). Keys to Soil Taxonomy. USDA Natural Resources Conservation Service. 12th ed., p. 372

Sparks D.L. (1996). Methods of Soil Analysis, Part 3 Chemical Methods. SSSA \& ASA. Madison, 1, 551-574

Storie R.E. (1933). An index for rating the agricultural value of soils. Bulletin - California Agricultural Experimental Station 556, University of California Agricultural Experimental Station, Berkley, CA

Sys C., Ranst V., Debaveye J. and Beernaert F. (1993). Land evaluation Part III, crop requirements. Agricultural Publication No. 7, ITC, Ghent.

Tabi F.O. and Ogunkunle A.O. (2007). Spatial variation of some soil physicochemical properties of an Alfisol in Southwestern Nigeria. Nigerian J. Soil Environ. Res., 7, 82-91

Tabi F.O., Omoko M., Boukong A., MvondoZe A.D., Bitondo D. and Fuh-Che C. (2012). Evaluation of lowland rice (Oryza sativa) production system and management recommendations for Logone and Chari floodplain-Republic of Cameroon. Agric. Sci. Res. J., 2 (5), 261-273

Walkley A. and Black I.A. (1934). An examination of the digestive method of determining soil organic matter, and a proposed modification of the chromic acid titration method. Soil Sci., 37: 29-38 